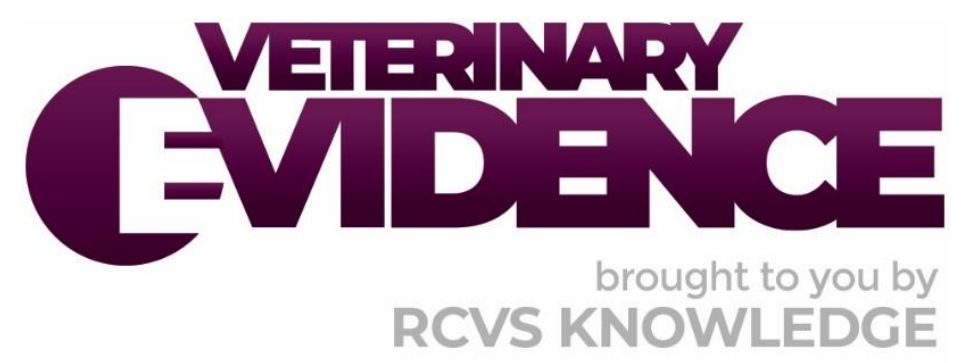

\title{
The effect of pre-emptive incisional bupivacaine block on postoperative pain after coeliotomy in dogs
}

\author{
A Knowledge Summary by
}

Kiriaki Pavlidou DVM PhD ${ }^{1 *}$

Lysimachos G Papazoglou DVM PhD MRCVS ${ }^{1}$

\footnotetext{
${ }^{1}$ Companion Animal Clinic, School of Veterinary Medicine, Department of Clinical Sciences, Aristotle University of Thessaloniki, Greece

*Corresponding Author (kellypav@gmail.com)
}

ISSN: 2396-9776

Published: 31 Mar 2021

in: The Veterinary Evidence journal Vol 6, Issue 1

DOI: $\underline{10.18849 / V E . V 6 I 1.325}$

Reviewed by: Latifa Khenissi (DVM MRCVS Dipl. ECVAA), Christopher Norkus (DVM DACVAA CVPP DACVECC) and Thomas Towers (VetMB MA CertAVP(VA) MRCVS)

Next Review Date: 30 Sep 2022 


\section{KNOWLEDGE SUMMARY}

\section{PICO question}

Is there an effect on analgesia following coeliotomy in dogs after a block with local anaesthetics?

\section{Clinical bottom line}

\section{Category of research question}

Treatment

\section{The number and type of study designs reviewed}

All the available evidence for this PICO question comes from clinical trials and one experimental/pharmacology study. All the studies were randomised; $5 / 7$ were blinded clinical studies and $4 / 7$ studies were prospective

\section{Strength of evidence}

Moderate

\section{Outcomes reported}

It is not clear if the use of a local anaesthetic including bupivacaine or lidocaine as incisional blocks minimises the postoperative pain especially in the first 24 hours, as the results are not statistically significant between the groups

\section{Conclusion}

In conclusion, bupivacaine or lidocaine can minimise the postoperative pain but more clinical trials are needed

\section{How to apply this evidence in practice}

The application of evidence into practice should take into account multiple factors, not limited to: individual clinical expertise, patient's circumstances and owners' values, country, location or clinic where you work, the individual case in front of you, the availability of therapies and resources.

Knowledge Summaries are a resource to help reinforce or inform decision making. They do not override the responsibility or judgement of the practitioner to do what is best for the animal in their care.

\section{The evidence}

All the available evidence for this PICO question comes from clinical trials and one experimental/pharmacology study. All the studies were randomised; 5/7 were blinded clinical studies and 4/7 studies were prospective. The strength of the evidence is not the strongest one as there is no meta-analysis research about this subject, however, it is moderate as most of the included trials were randomised clinical studies. 


\section{Abbreviations:}

\begin{tabular}{|l|l|}
\hline CMPS & Composite Measure Pain Scale \\
\hline DIVAS & dynamic and interactive visual analogue scale \\
\hline $\mathrm{EtCO}_{2}$ & end-tidal carbon dioxide concentration \\
\hline FPIA & fluorescence polarisation immunoassay technology \\
\hline HR & heart rate \\
\hline IM & intramuscularly \\
\hline IV & intravenously \\
\hline MWTs & mechanical wound thresholds \\
\hline NRS & numeric rating scale \\
\hline RR & respiratory rate \\
\hline SC & subcutaneously \\
\hline SpO 2 & oxygen saturation \\
\hline UMPS & University of Melbourne Pain Scale \\
\hline VAS & Visual Analogue Scale \\
\hline
\end{tabular}

\begin{tabular}{|c|c|}
\hline Population: & $\begin{array}{l}\text { Various breeds of healthy dogs participating in surgical training } \\
\text { exercises }\end{array}$ \\
\hline Sample size: & Six dogs \\
\hline Intervention details: & $\begin{array}{l}\text { - Dogs }(\mathrm{n}=6) \text { were premedicated with: Acepromazine at } 0.1 \pm \\
0.07 \mathrm{mg} / \mathrm{kg} \mathrm{IM} \text {, butorphanol at } 0.3 \pm 0.1 \mathrm{mg} / \mathrm{kg} \mathrm{IM} \\
\text { - } \quad \text { Induction with thiopental at } 11.5 \pm 2.7 \mathrm{mg} / \mathrm{kg} \mathrm{IV} \\
\text { - Maintenance with halothane or isoflurane } \\
\text { - The dose of lidocaine hydrochloride }(20 \mathrm{mg} / \mathrm{ml}) \\
\text { administered intraperitoneally was } 8.8 \mathrm{mg} / \mathrm{kg} \text {. The solution } \\
\text { was diluted with an equal volume of isotonic saline resulting } \\
\text { in a volume of } 0.88 \mathrm{~mL} / \mathrm{kg} \text {. This diluted solution was placed } \\
\text { into the peritoneal cavity just prior to closure of the incision } \\
\text { in the body wall. } \\
\text { - } 2 \mathrm{mg} / \mathrm{kg} \text { of } 2 \% \text { lidocaine hydrochloride with epinephrine was } \\
\text { placed in the wound after the closure of the abdominal wall. }\end{array}$ \\
\hline Study design: & Pharmacological experimental study, non-blinded, non-controlled \\
\hline Outcome studied: & $\begin{array}{l}\text { - Dogs were observed for signs of toxicity (seizures, nausea) at } \\
\text { each of the sampling periods and again } 18 \mathrm{~h} \text { after the drug } \\
\text { administration. } \\
\text { - Venous blood was collected through a catheter aseptically } \\
\text { placed in the cephalic or lateral saphenous vein. } \\
\text { - The baseline blood sample was collected once the dog was } \\
\text { anesthetised and in } 5,10,15,20 \text {, and } 30 \text { mins and } 1,2,3,4 \\
\text { and } 5 \text { hrs after the intraperitoneal (IP) injection. } \\
\text { The lidocaine assay utilised FPIA and a commercially } \\
\text { available reagent kit. }\end{array}$ \\
\hline
\end{tabular}




\begin{tabular}{|c|c|}
\hline $\begin{array}{l}\text { Main findings: } \\
\text { (relevant to PICO question): }\end{array}$ & $\begin{array}{l}\text { - No adverse consequences or signs of toxicity were noted } \\
\text { during the postoperative period in these dogs. } \\
\text { - Detectable concentrations of lidocaine were found in all } \\
\text { dogs in the sample taken } 5 \text { mins after administration. } \\
\text { - Time to peak serum concentration was } 0.37 \pm 0.26 \mathrm{hr} \text {. } \\
\text { - Peak serum concentration was } 1.45 \pm 0.36 \mu \mathrm{g} / \mathrm{mL} \text {. } \\
\text { - A rapid decrease in serum concentration was shown with an } \\
\text { elimination half-life of } 1.17 \pm 0.11 \mathrm{hr} \text {. }\end{array}$ \\
\hline Limitations: & $\begin{array}{l}\text { - Small sample size. } \\
\text { - Non-controlled, non-blinded study. } \\
\text { - } \text { No details about which dogs receive halothane and which } \\
\text { - Anaesthetic values were not mentioned in the results. }\end{array}$ \\
\hline
\end{tabular}

\section{Carpenter at al. (2004)}

\begin{tabular}{|c|c|}
\hline Population: & $\begin{array}{l}\text { Client-owned dogs or from local humane societies and rescue } \\
\text { groups presented to Veterinary Hospital for routine } \\
\text { ovariohysterectomy. } \\
\text { They were determined to be healthy by physical examination. } \\
\text { Dogs were excluded if they were less than } 1 \text { year of age, weighed } \\
\text { less than } 4.5 \mathrm{~kg} \text {, or were having other procedures performed in } \\
\text { addition to ovariohysterectomy. }\end{array}$ \\
\hline Sample size: & $\begin{array}{l}30 \text { dogs } \\
13 \text { mixed-breed dogs, } 17 \text { purebred dogs }\end{array}$ \\
\hline Intervention details: & $\begin{array}{l}\text { - } 10 \text { dogs in saline group (SAL), } 10 \text { dogs in lidocaine group } \\
\text { (LID) and } 10 \text { dogs in bupivacaine group (BUP). } \\
\text { - } \quad \text { Premedication with } 0.02 \mathrm{mg} / \mathrm{kg} \text { acepromazine IM and } 0.22 \\
\mathrm{mg} / \mathrm{kg} \text { butorphanol IM. } \\
\text { - } \quad \text { Induction with thiopental sodium at } 13.2 \mathrm{mg} / \mathrm{kg} \mathrm{IV} \\
\text { - } \quad \text { Intraintenance of anaesthesia with isoflurane in oxygen. } \\
\text { - Before closure of the linea alba following the procedure, } 10 \\
\text { dogs received } 0.88 \mathrm{~mL} / \mathrm{kg} 0.9 \% \text { saline, } 10 \text { dogs received } 8.8 \\
\mathrm{mg} / \mathrm{kg} 2 \% \text { lidocaine with epinephrine diluted to an } \\
\text { equivalent volume with saline and } 10 \text { dogs received } 4.4 \\
\mathrm{mg} / \mathrm{kg} 0.75 \% \text { bupivacaine diluted to an equivalent volume } \\
\text { with saline in their IP space at the cranial site of the incision. } \\
\text { - Prior to closure of the skin, the SAL dogs received } 2.0 \mathrm{~mL} \text { of } \\
0.9 \% \text { saline, the LID dogs received } 2.0 \mathrm{~mL} \text { of } 2 \% \text { lidocaine } \\
\text { with epinephrine and the BUP dogs received } 2.0 \mathrm{~mL} \text { of } \\
\text { 0.75\% bupivacaine as a splash on linea alba. } \\
\text { - General anaesthesia was maintained until skin closure. } \\
\text { - The dogs were placed in sternal recumbency for } 10 \text { minutes } \\
\text { after the recovery from anaesthesia. } \\
\text { - Dogs with a pain score greater than } 50 \mathrm{~mm} \text { on the VAS-pain } \\
\text { at any time were given } 0.22 \mathrm{mg} / \mathrm{kg} \text { butorphanol IV or IM. } \\
\text { Dogs that were extremely agitated or they did not respond } \\
\text { to butorphanol were given additional doses of butorphanol } \\
\text { and/or acepromazine as needed. }\end{array}$ \\
\hline
\end{tabular}




\begin{tabular}{|c|c|}
\hline Study design: & Prospective, randomised, controlled, blinded clinical trial \\
\hline Outcome studied: & $\begin{array}{l}\text { - Pre- and post-procedural pain scoring was performed using } \\
\text { the CMPS and VAS by one observer. } \\
\text { - Pain scores at baseline, } 0.5,1,2,3,4,6,8 \text { and } 18 \text { hrs post } \\
\text { extubation. } \\
\text { - The scorer first observed the dog quietly for } 1 \text { min outside } \\
\text { the cage. Then, he rattled the cage door and entered the } \\
\text { cage saying hello. } \\
\text { - RR was measured at the first minute of observation. } \\
\text { - Behaviour and HR were recorded. } \\
\text { - Palpation of the incision was performed by handler gently } \\
\text { - } \text { three times. } \\
\text { Position, activity and vocalisation were recorded during } \\
\text { - Puiet observation. } \\
\text { Position change and behaviour were recorded during the } \\
\text { opening of the cage door. } \\
\text { A single number from the CMPS was recorded at each time } \\
\text { period. VAS scores were recorded by placing a cross on a } \\
100 \text { mm line between "no pain" and "worst imaginable } \\
\text { pain" for pain scores (VAS-pain) and between "no sedation" } \\
\text { and "very sedate" for sedation scores (VAS-sedation). } \\
\text { - All treated dogs were scored throughout the surgery. } \\
\text { - The length of the incision was measured upon completion of } \\
\text { surgery. } \\
\text { Observation for signs of local anaesthetic toxicity (sedation, } \\
\text { nausea, seizures). }\end{array}$ \\
\hline $\begin{array}{l}\text { Main findings: } \\
\text { (relevant to PICO question): }\end{array}$ & $\begin{array}{l}\text { - } 7 / 10 \text { dogs in SAL group, } 4 / 10 \text { in LID group and } 2 / 10 \text { in BUP } \\
\text { group were given supplemental analgesia (significantly more } \\
\text { dogs in SAL group than in BUP group). } \\
\text { - } 2 / 7 \text { dogs in SAL group were given two doses of analgesics. } \\
\text { - Dogs in LID group were given supplemental analgesia at } 0.5 \text {, } \\
1,2 \text { and } 3 \text { hrs after extubation. Two out of four dogs in LID } \\
\text { group were given two doses of supplemental analgesia. } \\
\text { - In BUP group dogs were given supplemental analgesia } 1 \mathrm{hr} \\
\text { after extubation and only with butorphanol. } \\
\text { - None of the dogs in BUP group were given supplemental } \\
\text { analgesia more than once. } \\
\text { - None of the dogs received supplemental analgesics after } 3 \\
\text { hrs post-extubation. } \\
\text { VAS-pain scores: a mean of } 52 \pm 24 \text { at } 0.5 \text { hrs to } 2 \pm 3 \text { at } 18 \\
\text { hrs for the SAL group, a mean of } 40 \pm 19 \text { at } 0.5 \text { hrs to } 1 \pm 3 \text { at } \\
18 \text { hrs for LID group and } 27 \pm 4 \text { at } 0.5 \text { hrs to } 2 \pm 1 \text { at } 18 \text { hrs } \\
\text { for the BUP group. } \\
\text { - No significant difference among groups between VAS-pain } \\
\text { scores at times } 0.5 \text { and } 18 \text { hrs. } \\
\text { Dogs in BUP group had statistically significant lower pain } \\
\text { scores than dogs in SAL group. } \\
\text { At } 0.5 \text { hrs: BUP group had significantly lower pain scores } \\
\text { than LID and SAL scores. }\end{array}$ \\
\hline
\end{tabular}




\begin{tabular}{|c|c|}
\hline & $\begin{array}{l}\text { CMPS scores: a mean of } 7.4 \pm 3.9 \text { at } 0.5 \text { hrs to } 0.1 \pm 0.3 \text { at } 18 \\
\text { hrs for the SAL group, } 5.0 \pm 2.3 \text { at } 0.5 \text { hrs to } 0.2 \pm 0.4 \text { at } 18 \\
\text { hrs for the LID group and } 3.5 \pm 2.1 \text { at } 0.5 \text { hrs to } 0.7 \pm 0.7 \text { at } \\
18 \text { hrs for the BUP group. } \\
\text { - Significantly lower CMPS score at } 0.5 \text { hrs in BUP group than } \\
\text { in SAL group. } \\
\text { - VAS-sedation scores: a mean of } 83 \pm 7 \text { at } 0.5 \text { hrs to } 2 \pm 2 \text { at } \\
18 \text { hrs for the SAL group, } 82 \pm 9 \text { to } 2 \pm 3 \text { for the LID group } \\
\text { and } 73 \pm 14 \text { to } 1 \pm 1 \text { for BUP group. } \\
\text { BUP dogs were significantly less sedated than the SAL dogs. }\end{array}$ \\
\hline Limitations: & $\begin{array}{l}\text { - Pain scores were subjective, but the observer was well } \\
\text { trained. } \\
\text { - The exact p-values for the statistically significant differences } \\
\text { were not displayed in the results. }\end{array}$ \\
\hline
\end{tabular}

Savvas et al. (2008)

\begin{tabular}{|c|c|}
\hline Population: & $\begin{array}{l}\text { Dogs that were presented for midline coeliotomy. } \\
\text { Dogs that were in the American Society of Anesthesiologists (ASA) } \\
\text { physical status classification system }>3 \text {, were excluded from the } \\
\text { study. }\end{array}$ \\
\hline Sample size: & 60 dogs ( 35 females, 25 males) \\
\hline Intervention details: & 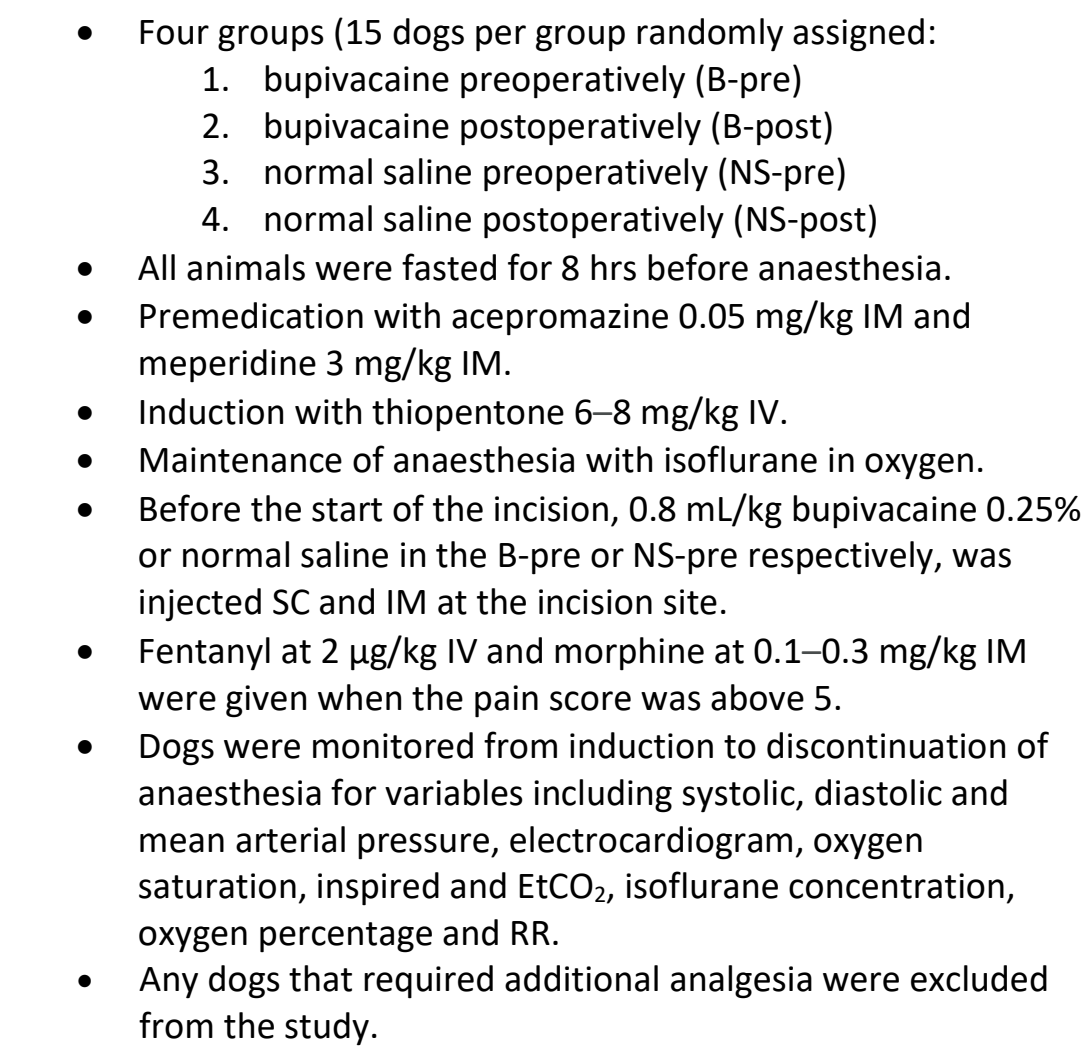 \\
\hline Study design: & Blinded, placebo-controlled, randomised clinical trial \\
\hline Outcome studied: & $\begin{array}{l}\text { Pain and sedation were scored at } 1,2,3,4,5,6,16 \text { to } 20 \text { and } 24 \mathrm{hrs} \\
\text { after surgery. Pain was assessed based on a numerical scale from } 0 \\
\text { to } 10 \text { ( } 0=\text { no pain, } 10=\text { full pain) and sedation based on another }\end{array}$ \\
\hline
\end{tabular}




\begin{tabular}{|c|c|}
\hline & $\begin{array}{l}\text { scoring system ( } 0=\text { fully alert, } 1=\text { alert but unable to walk, } 2=\text { drowsy } \\
\text { and unable to stand and } 3=\text { heavily sedated/asleep). } \\
\text { After surgery, the dog's posture, behaviour, vocalisation, and } \\
\text { food/water consumption, the willingness to move and the pattern of } \\
\text { locomotion and the response to the palpation of the incision area } \\
\text { were noted. }\end{array}$ \\
\hline $\begin{array}{l}\text { Main findings: } \\
\text { (relevant to PICO question): }\end{array}$ & $\begin{array}{l}\text { Maximal pain score (mean } \pm \text { SD) for B-pre: } 3.67 \pm 1.11 \text {, B- } \\
\text { post: } 5.20 \pm 1.30, \text { NS-pre: } 6.67 \pm 1.59, \text { NS-post: } 6.53 \pm 1.13 \text {. } \\
\text { - Time points of pain scores: } 2 \text { hrs after surgery in } 48 / 60 \text { dogs, } \\
3 \text { hrs after surgery in } 55 / 60 \text { dogs and within } 4 \mathrm{hrs} \text { in } 60 / 60 \text {. } \\
\text { - Supplemental postoperative analgesia: B-pre: } 0 / 15, B-p o s t \text { : } \\
\text { 7/15, NS-pre: } 11 / 15, \text { NS-post: } 11 / 15 \text {. } \\
\text { - Statistically significant difference was the mean maximal } \\
\text { pain score between the B-pre group and the other three } \\
\text { groups. } \\
\text { B-pre group was also statistically different from the other } \\
\text { three groups concerning less additional postoperative } \\
\text { analgesia ( }<<0.0005) \text {. }\end{array}$ \\
\hline Limitations: & $\begin{array}{l}\text { - No power calculation. } \\
\text { - The choice of the pain score as it was based on behavioural } \\
\text { criteria. } \\
\text { The duration of the surgery was not recorded but the } \\
\text { duration of anaesthesia was monitored. }\end{array}$ \\
\hline
\end{tabular}

Fitzpatrick et al. (2010)

\begin{tabular}{|c|c|}
\hline Population: & $\begin{array}{l}\text { Shelter-owned, sexually intact, female dogs of various ages and } \\
\text { breeds }\end{array}$ \\
\hline Sample size: & 92 dogs randomly assigned in four groups \\
\hline Intervention details: & 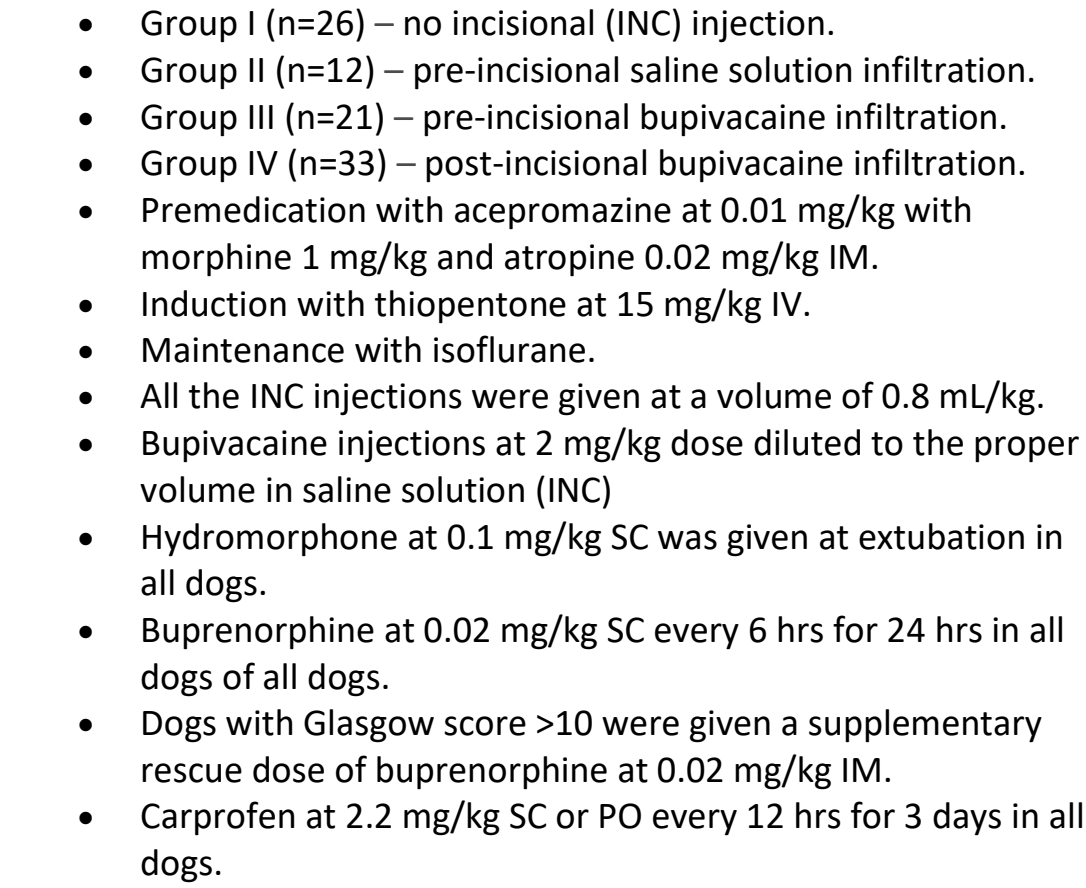 \\
\hline
\end{tabular}




\begin{tabular}{|c|c|}
\hline Study design: & Blinded, randomised, controlled clinical trial \\
\hline Outcome studied: & $\begin{array}{l}\text { Pain assessment at } 4,8,12 \text { and } 24 \text { hrs after surgery with Glasgow } \\
\text { scale and von Frey filaments. } \\
\text { Incision assessment at } 4,8,12 \text { and } 24 \text { hrs after surgery for } \\
\text { oedema, erythema, discharge, INC infection or dehiscence. }\end{array}$ \\
\hline $\begin{array}{l}\text { Main findings: } \\
\text { (relevant to PICO question): }\end{array}$ & $\begin{array}{l}\text { - Incision length was significantly greater in Group III. } \\
\text { - Glasgow pain scores were significantly decreased from } 4 \text { to } \\
24 \text { hrs in Groups I, III and IV. No statistically significant } \\
\text { decrease for the same hours in Group II ( } p=0.125 \text { ). } \\
\text { - No dog with Glasgow pain score }>10 \text {. } \\
\text { - Von Frey filament score did not differ significantly for Group } \\
\text { I, III and IV from } 4 \text { to } 24 \text { hours. This score was significantly } \\
\text { decreased in Group II ( } p=0.031 \text { ). } \\
\text { - There was a higher rate of complications by the time of the } \\
\text { suture removal in dogs that received pre-incisional } \\
\text { infiltration of bupivacaine compared with dogs that received } \\
\text { no injection at the incision site. However, bupivacaine was } \\
\text { not indicated for the higher rate of complications in this } \\
\text { group. }\end{array}$ \\
\hline Limitations: & $\begin{array}{l}\text { - Ovariohysterectomy was performed by non-experienced } 4^{\text {th }} \\
\text { year veterinary students and this may have affected the } \\
\text { results as they had a greater inexperience. } \\
\text { - No equal number of dogs in each group because of } \\
\text { scheduling conflicts and the availability of investigators. } \\
\text { - High dose of morphine as premedication and thiopental for } \\
\text { induction. } \\
\text { - Postoperative analgesia with hydromorphone, } \\
\text { buprenorphine and carprofen in all dogs independently of } \\
\text { the pain scores may have affected the results as none of the } \\
\text { dogs required rescue analgesia. }\end{array}$ \\
\hline
\end{tabular}

Campagnol et al. (2012)

\begin{tabular}{|c|c|}
\hline Population: & Client owned rescue dogs undergoing ovariohysterectomy \\
\hline Sample size: & 30 female dogs randomly assigned to three groups \\
\hline Intervention details: & $\begin{array}{l}\text { - The treatments consisted of administration of } 0.9 \% \mathrm{NaCl} \\
\text { and/or } 0.5 \% \text { bupivacaine with epinephrine either by the IP } \\
\text { and/or INC route. } \\
\text { - Control group }(\mathrm{n}=10) \text { - saline solution IP and INC. } \\
\text { - IP group }(\mathrm{n}=10) \text { - bupivacaine } 5 \mathrm{mg} / \mathrm{kg} \mathrm{IP} \text { and saline solution } \\
\text { INC. } \\
\text { - INC group }(\mathrm{n}=10)-\text { saline solution IP and bupivacaine } 1 \\
\mathrm{mg} / \mathrm{kg} \mathrm{INC} \text {. } \\
\text { - Acepromazine } 0.05 \mathrm{mg} / \mathrm{kg} \text { and butorphanol } 0.2 \mathrm{mg} / \mathrm{kg} \text { as } \\
\text { premedication. } \\
\text { - Thiopental } 10 \mathrm{mg} / \mathrm{kg} \text { intravenously for induction. } \\
\text { Blinded single surgeon performed all the procedures and the } \\
\text { administration of the solutions. }\end{array}$ \\
\hline
\end{tabular}




\begin{tabular}{|c|c|}
\hline & $\begin{array}{l}\text { - Rescue analgesia with morphine }(0.5 \mathrm{mg} / \mathrm{kg} \mathrm{IM}) \text { was given if } \\
\text { VAS or NRS scores were higher than } 5 \text { and } 10 \text { respectively. }\end{array}$ \\
\hline Study design: & Prospective, blinded, randomised clinical study \\
\hline Outcome studied: & $\begin{array}{l}\text { - During postoperative period, any signs of local anaesthetic } \\
\text { toxicity were recorded. } \\
\text { - Postoperative pain and sedation were evaluated 1, 2, 3, 4, 6, } \\
12 \text { and } 24 \text { hrs after extubation. It was evaluated through } \\
\text { NRS from 0-29 and VAS from 0-10. } \\
\text { - VAS scores for both pain and sedation were performed } \\
\text { without interaction with the dog. } \\
\text { - Non-interactive parameters were evaluated before } \\
\text { interactive parameters during NRS scoring. } \\
\text { - Client-owned rescue dogs continued to be scored } \\
\text { throughout the } 24 \text { hr observation period and data obtained } \\
\text { from these dogs were included in the statistical analysis. }\end{array}$ \\
\hline $\begin{array}{l}\text { Main findings: } \\
\text { (relevant to PICO question): }\end{array}$ & 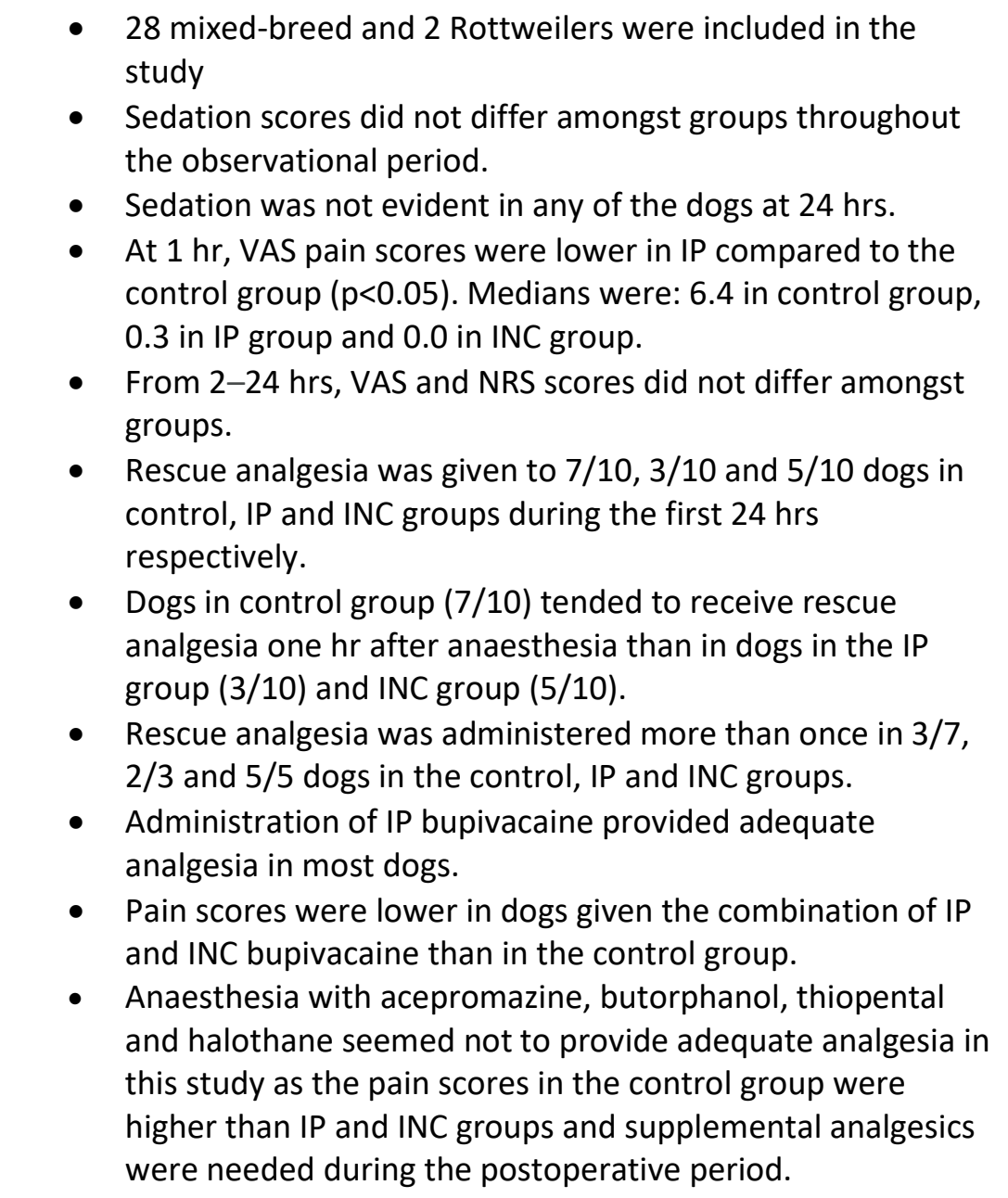 \\
\hline Limitations: & $\begin{array}{l}\text { - Small number of subjects in each group without power } \\
\text { calculation. } \\
\text { - Client owned rescue dogs usually excluded from the study as } \\
\text { this may affect the overall results. } \\
\text { - Large volume of bupivacaine is necessary for the IP } \\
\text { administration as the dose of bupivacaine was five times } \\
\text { higher than that used in the INC group. }\end{array}$ \\
\hline
\end{tabular}




\begin{tabular}{|c|c|}
\hline Population: & Female dogs undergoing ovariohysterectomy \\
\hline Sample size: & 38 dogs randomly allocated in two groups \\
\hline Intervention details: & $\begin{array}{l}\text { - Lidocaine group (L) } \mathrm{n}=19 \text { - received a continuous lidocaine } \\
\text { infusion ( } 2 \mathrm{mg} / \mathrm{kg} / \mathrm{hr} \text { ) through a wound catheter in the } \\
\text { peritoneal space. } \\
\text { - Control group } \mathrm{n}=19 \text { - received methadone at } 0.2 \mathrm{mg} / \mathrm{kg} \mathrm{IM} \\
\text { every } 4 \text { hours after premedication. } \\
\text { - Medetomidine at } 3 \mu \mathrm{gg} / \mathrm{kg} \mathrm{IM} \text { and methadone at } 0.3 \mathrm{mg} / \mathrm{kg} \\
\text { IM were given as premedication. } \\
\text { - Induction with propofol and maintenance of anaesthesia } \\
\text { with isoflurane. } \\
\text { - Rescue analgesia with methadone at } 0.3 \mathrm{mg} / \mathrm{kg} \text { IV was given } \\
\text { when CMPS-SF score }>6 \text { or DIVAS }>50 \mathrm{~mm} \text {. }\end{array}$ \\
\hline Study design: & Prospective, non-blinded, randomised clinical study \\
\hline Outcome studied: & $\begin{array}{l}\text { - } \mathrm{HR}, \mathrm{RR}, \mathrm{EtCO}_{2}, \mathrm{SpO}_{2} \text { and non-invasive arterial blood pressure } \\
\text { were recorded. } \\
\text { - Pain assessment at baseline, 2, 4, 6, } 18 \text { and } 24 \mathrm{hrs} \text { after the } \\
\text { end of anaesthesia. } \\
\text { - Three pain assessment systems: DIVAS, Glasgow scale } \\
\text { (CMPS-SF) and MWTs. } \\
\text { - Sedation assessment at baseline, 2, 4, 6, } 18 \text { and } 24 \mathrm{hrs} \text {. } \\
\text { - Lidocaine and cortisol levels were measured at baseline, 2, } \\
6,18 \text { and } 24 \mathrm{hrs} \text { after the completion of the surgery. }\end{array}$ \\
\hline $\begin{array}{l}\text { Main findings: } \\
\text { (relevant to PICO question): }\end{array}$ & $\begin{array}{l}\text { - No difference in analgesic parameters between the two } \\
\text { groups. } \\
\text { - In control group, methadone was given at } 1 \text { and } 5 \text { hrs after } \\
\text { the end of the surgery. } \\
\text { - Rescue analgesia was given to } 4 / 19 \text { animals in control group } \\
\text { and } 0 / 19 \text { in the } L \text { group. } \\
\text { - Mean lidocaine continuous rate infusion (CRI) volume was } \\
3.17 \pm 0.89 \mathrm{~mL} / \mathrm{hr} \text {. }\end{array}$ \\
\hline Limitations: & $\begin{array}{l}\text { - Absence of blinding. } \\
\text { - Two dogs removed the wound catheters before the end of } \\
\text { the study. } \\
\text { - Dysphoria was the most frequent adverse effect. } \\
\text { - No statistically significant differences between the groups. }\end{array}$ \\
\hline
\end{tabular}

McKune et al. (2014)

\begin{tabular}{|r|c|}
\hline Population: & Healthy female dogs undergoing ovariohysterectomy \\
\hline Sample size: & 59 dogs randomly allocated in to three groups \\
\hline Intervention details: & $\begin{array}{r}\text { All three groups were sedated with acepromazine at } 0.03 \\
\end{array}$ \\
& $\begin{array}{l}\mathrm{mg} / \mathrm{kg} \mathrm{SC} . \\
\text { - Induction with propofol and maintenance with isoflurane. } \\
\end{array}$ \\
& $\begin{array}{l}\text { L/B (lidocaine/bupivacaine) group ( } \mathrm{n}=20 \text { ): line } \mathrm{block} \text { prior to } \\
\text { the incision with lidocaine at } 4 \mathrm{mg} / \mathrm{kg} \text { and } 1 \mathrm{mg} / \mathrm{kg} \text { of }\end{array}$ \\
\hline
\end{tabular}




\begin{tabular}{|c|c|}
\hline & $\begin{array}{l}\text { bupivacaine. Saline at } 0.05 \mathrm{mg} / \mathrm{kg} \mathrm{SC} \text { was given at the same } \\
\text { time with acepromazine. } \\
\text { L/BM (lidocaine/bupivacaine-morphine) group ( } \mathrm{n}=19 \text { ): line } \\
\text { block prior to the incision with lidocaine at } 4 \mathrm{mg} / \mathrm{kg} \text { and } 1 \\
\mathrm{mg} / \mathrm{kg} \text { of bupivacaine. Morphine at } 0.5 \mathrm{mg} / \mathrm{kg} \mathrm{SC} \text { was given } \\
\text { at the same time with acepromazine. } \\
\text { - SS (normal saline/normal saline) group ( } \mathrm{n}=20 \text { ): } 0.275 \mathrm{ml} / \mathrm{kg} \\
\text { of normal saline prior to surgery in the INC area and } 0.05 \\
\mathrm{mg} / \mathrm{kg} \text { of saline } \mathrm{SC} \text { at the same time with acepromazine. } \\
\text { - Pain was assessed prior to the sedation (time negative } \\
\text { zone), zero time (time of extubation), } 2,4,6,8 \text { and } 24 \mathrm{hrs} \\
\text { post-surgery. } \\
\text { - One blinded veterinarian. } \\
\text { - Rescue analgesia was morphine at } 0.5 \mathrm{mg} / \mathrm{kg} \mathrm{IM} \text { and given } \\
\text { to: } \quad \text { any animal that achieved a maximum score in any } \\
\quad \text { one category of the GCPS; } \\
\text { any animal with a pain score of } 8 \text { or greater on the } \\
\text { GCPS; } \\
\text { any animal who did not improve over time as } \\
\text { compared to pre-sedation GCPS score; } \\
\circ \quad \text { any animal developing aggression; } \\
\circ \quad \text { or any animal with a combination of these previous } \\
\text { factors. }\end{array}$ \\
\hline Study design: & Prospective, randomised, blinded clinical trial \\
\hline Outcome studied: & $\begin{array}{l}\text { HR, RR and systolic blood pressure were recorded } \\
\text { Four pain score systems: VAS, Glasgow scale (GCPS), UMPS and von } \\
\text { Frey }\end{array}$ \\
\hline $\begin{array}{r}\text { Main findings: } \\
\text { (relevant to PICO question): }\end{array}$ & $\begin{array}{l}\text { - 20/59 dogs required rescue analgesia (7/20 in L/B group, 3/ } \\
19 \text { in L/BM group and 10/20 in SS group). } \\
\text { - VAS, GCPS and UMPS analyses showed no significant } \\
\text { differences in pain score systems between groups. } \\
\text { - No statistically significant difference between the positive } \\
\text { (L/BM) and negative group (SS) at any given time point. }\end{array}$ \\
\hline Limitations: & $\begin{array}{l}\text { - No significant difference between pain scores for any } \\
\text { treatment group as the sample size was small. The initial } \\
\text { sample size calculations hindered the study in two ways. In } \\
\text { order to correctly calculate the initial sample size, the } p \text { - } \\
\text { value should be corrected to } 0.017 \text { and this was not done. } \\
\text { - Low pain scores may be due to inherent insensitivity of the } \\
\text { measurement techniques preventing a significant difference } \\
\text { between negative and positive controls. } \\
\text { Von Frey may not be appropriate for assessing sensitivity of } \\
\text { clinical wounds according to previous studies. }\end{array}$ \\
\hline
\end{tabular}




\section{Appraisal, application and reflection}

The purpose of this Knowledge Summary was to look at the evidence for the use of bupivacaine through the line block in dogs undergoing midline coeliotomy. Seven papers were identified as relevant to this question.

Five out of seven were blinded clinical trials (Carpenter et al., 2004; Savvas et al., 2008; Fitzpatrick et al., 2010; Campagnol et al., 2012; and McKune at al., 2014), four out of seven were prospective clinical studies (Carpenter et al., 2004; Campagnol et al., 2012; Morgaz et al., 2014; and McKune at al., 2014) and one was an experimental, pharmacology, non-blinded, non-controlled study.

Only one study (Savvas et al., 2008) evaluated the effectiveness of pre-emptive incisional block with bupivacaine on postoperative pain and opioid requirements after coeliotomy in dogs. According to this, preoperative wound infiltration with bupivacaine is an effective technique to reduce postoperative pain but further studies are needed.

Back to 2004, there were two clinical studies. The first one, Wilson et al. (2004), determined the safe dose of intraperitoneal and incisional lidocaine applied in dogs undergoing ovariohysterectomy but no evaluation of pain scores was reported. The second was by Carpenter et al. (2004) where they found that intraperitoneal and incisional bupivacaine provided effective analgesia following ovariohysterectomy in dogs. In contrast, Fitzpatrick at al. (2010) found that there is no any additional analgesic benefit of infiltration with bupivacaine at the incision site, given either pre-emptively or following surgery when used as part of multimodal analgesic protocol for dogs undergoing routine ovariohysterectomy.

Another study (Campagnol et al., 2012) compared the effect of intraperitoneal or incisional bupivacaine on pain and analgesic requirement after ovariohysterectomy in dogs without any statistical difference.

There was only one clinical trial (Morgaz et al., 2014) where lidocaine was used through the intra-peritoneal continuous wound infusion for pain control following ovariohysterectomy in dogs, but the results were not statistically significant as the postoperative analgesia was similar to the analgesia provided by methadone.

Lidocaine and bupivacaine were used as a pre-incisional local anaesthetic block in dogs undergoing ovariohysterectomy (McKune et al., 2014). However, even in this prospective, blinded, randomised clinical trial, there were no firm conclusions about whether or not this line block is effective.

In conclusion, it is not clear if the use of a local anaesthetic including bupivacaine or lidocaine as incisional blocks minimises the postoperative pain especially in the first 24 hours, as the results are not statistically significant between the groups. As the sample sizes were so small and multiple analgesics were used in the clinical trials, further studies are necessary. 


\section{Methodology Section}

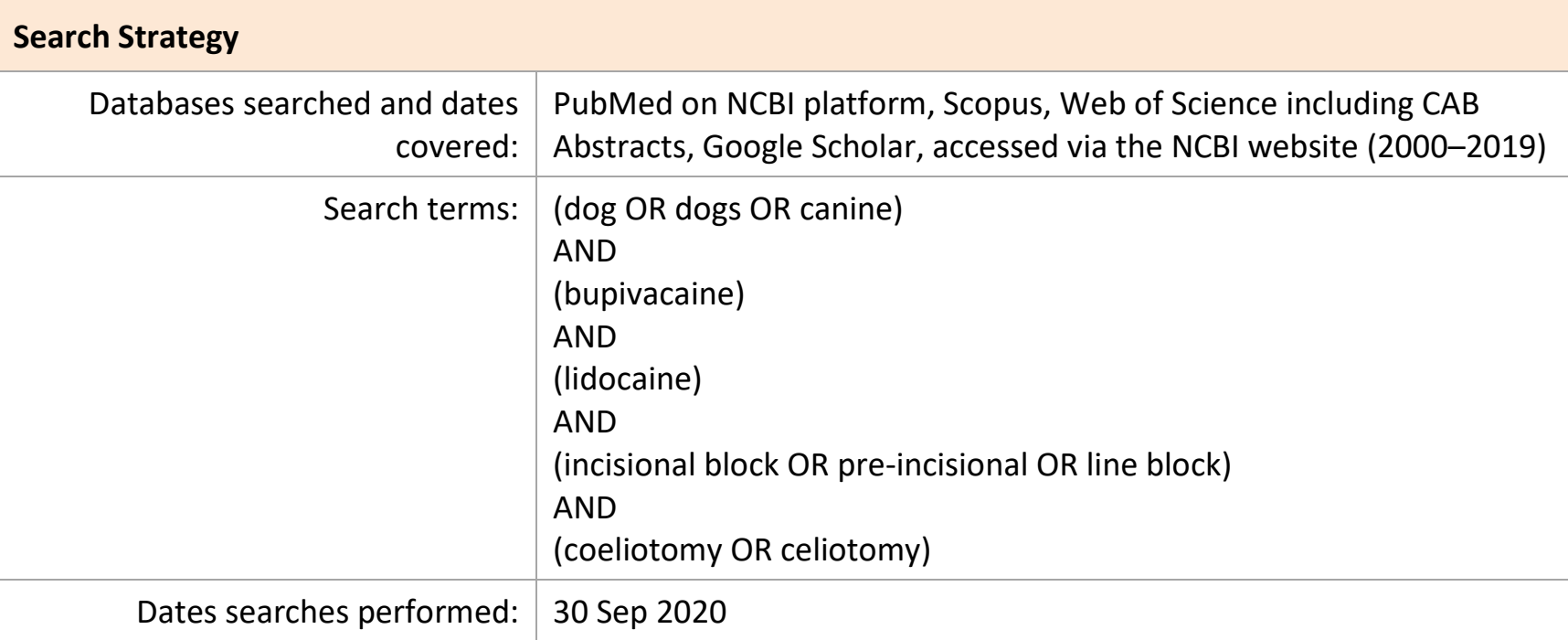

\section{Exclusion / Inclusion Criteria}

Exclusion: Articles not available in English, single case reports, book chapters, articles which were not relevant to the PICO question, articles listed on but not provided by the searched databases

Inclusion: Articles available in English which were relevant to the question

\begin{tabular}{|l|c|c|c|c|}
\hline \multicolumn{1}{|c|}{ Search Outcome } \\
\hline \multicolumn{1}{|c|}{ Database } & $\begin{array}{c}\text { Number of } \\
\text { results }\end{array}$ & $\begin{array}{c}\text { Excluded - Not } \\
\text { relevant to the PICO } \\
\text { question }\end{array}$ & $\begin{array}{c}\text { Excluded - Other } \\
\text { animals }\end{array}$ & $\begin{array}{c}\text { Total relevant } \\
\text { papers }\end{array}$ \\
\hline PubMed & 11 & 8 & 0 & 3 \\
\hline Scopus & 9 & 2 & 0 & 7 \\
\hline Web of Science & 8 & 2 & 10 & 7 \\
\hline Google Scholar & 91 & 74 & & 7 \\
\hline
\end{tabular}




\section{CONFLICT OF INTEREST}

The authors declare no conflict of interest.

\section{REFERENCES}

1. Campagnol, D., Teixeira-Neto, F. J., Monteiro, E. R., Restitutti, F. \& Minto, B. W. (2012). Effect of intraperitoneal or incisional bupivacaine on pain and the analgesic requirement after ovariohysterectomy in dogs. Veterinary Anaesthesia and Analgesia. 39(4), 426-430. DOI: https://doi.org/10.1111/j.1467-2995.2012.00728.x

2. Carpenter, R., Wilson, D. \& Evans, A. (2004). Evaluation of intraperitoneal and subcutaneous lidocaine and bupivacaine for analgesia following ovariohysterectomy in the dog. Veterinary Anaesthesia and Analgesia. 31(1), 46-52. DOI: https://doi.org/1111/j.1467-2995.2004.00137.x

3. Fitzpatrick, C. L., Weir, H. L. \& Monnet, E. (2010). Effects of infiltration of the incision site with bupivacaine on postoperative pain and incisional healing in dogs undergoing ovariohysterectomy. Journal of the American Veterinary Medical Association. 237(4), 395-401. DOI: https://doi.org/10.2460/javma.237.4.395

4. McKune, C. M., Pascoe, P. J., Lascelles, B. D. X. \& Kass, P. H. (2014). The challenge of evaluating pain and a pre-incisional local anesthetic block. PeerJ. 2(1), e341. DOI: https://doi.org/10.7717/peeri.341

5. Morgaz, J., Muñoz-Rascón, P., Serrano-Rodríguez, J. M., Navarrete, R., Domínguez, J. M., FernándezSarmiento, J. A., Gómez-Villamandos, R. J., Serrano, J. M. \& del Mar Granados, M. (2014). Effectiveness of pre-peritoneal continuous wound infusion with lidocaine for pain control following ovariohysterectomy in dogs. Veterinary Journal. 202(3), 522-526.

DOI: https://doi.org/10.1016/j.tvjl.2014.08.030

6. Savvas, I., Papazoglou, L. G., Kazakos, G., Anagnostou, T., Tsioli, V. \& Raptopoulos, D. (2008). Incisional Block With Bupivacaine for Analgesia After Celiotomy in Dogs. Journal of the American Animal Hospital Association. 44(2), 60-66. DOI: https://doi.org/10.5326/0440060

7. Wilson, D. V., Barnes, K. S. \& Hauptman, J. G. (2004). Pharmacokinetics of combined intraperitoneal and incisional lidocaine in the dog following ovariohysterectomy. Journal of Veterinary Pharmacology and Therapeutics. 27(2), 105-109. DOI: https://doi.org/10.1111/i.1365-2885.2004.00552.x 


\section{EVIIDEFeE

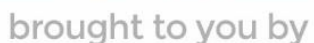 \\ RCVS KNOWLEDGE}

\section{Intellectual Property Rights}

Authors of Knowledge Summaries submitted to RCVS Knowledge for publication will retain copyright in their work, and will be required to grant RCVS Knowledge a non-exclusive license of the rights of copyright in the materials including but not limited to the right to publish, re-

publish, transmit, sell, distribute and otherwise use the materials in all languages and all media throughout the world, and to license or permit others to do so.

\section{Disclaimer}

Knowledge Summaries are a peer-reviewed article type which aims to answer a clinical question based on the best available current evidence. It does not override the responsibility

of the practitioner. Informed decisions should be made by considering such factors as individual clinical expertise and judgement along with patient's circumstances and owners' values. Knowledge Summaries are a resource to help inform and any opinions expressed within the Knowledge Summaries are the author's own and do not necessarily reflect the view of the RCVS Knowledge. Authors are responsible for the accuracy of the content. While the

Editor and Publisher believe that all content herein are in accord with current recommendations and practice at the time of publication, they accept no legal responsibility

for any errors or omissions, and make no warranty, express or implied, with respect to material contained within.

For further information please refer to our Terms of Use.

RCVS Knowledge is the independent charity associated with the Royal College of Veterinary Surgeons (RCVS). Our ambition is to become a global intermediary for evidence based veterinary knowledge by providing access to information

that is of immediate value to practicing veterinary professionals and directly contributes to evidence based clinical decision-making.

\section{https://www.veterinaryevidence.org/}

RCVS Knowledge is a registered Charity No. 230886.

Registered as a Company limited by guarantee in England and Wales No. 598443.

Registered Office: Belgravia House, 62-64 Horseferry Road, London SW1P 2AF

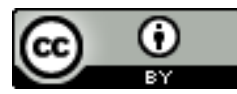

This work is licensed under a Creative Commons Attribution 4.0 International License 